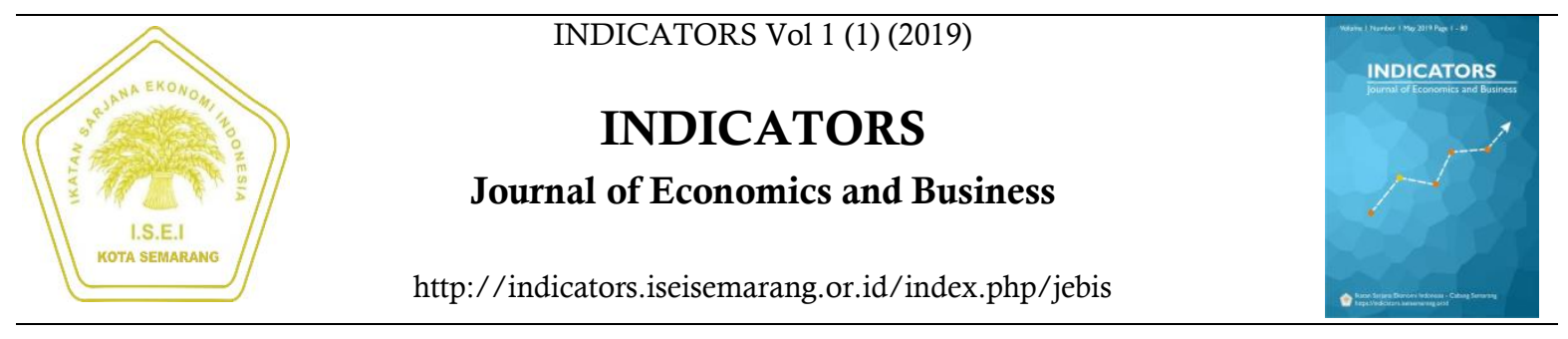

\title{
Analisis Tingkat Kesejahteraan Masyarakat Nelayan Buruh di Kecamatan Bonang Kabupaten Demak
}

\section{Dian Daru Wijayanto ${ }^{1 凶}$, Sucihatiningsih Dian Wisika Prajanti ${ }^{2}$}

Jurusan Ekonomi Pembangunan, Fakultas Ekonomi, Universitas Negeri Semarang

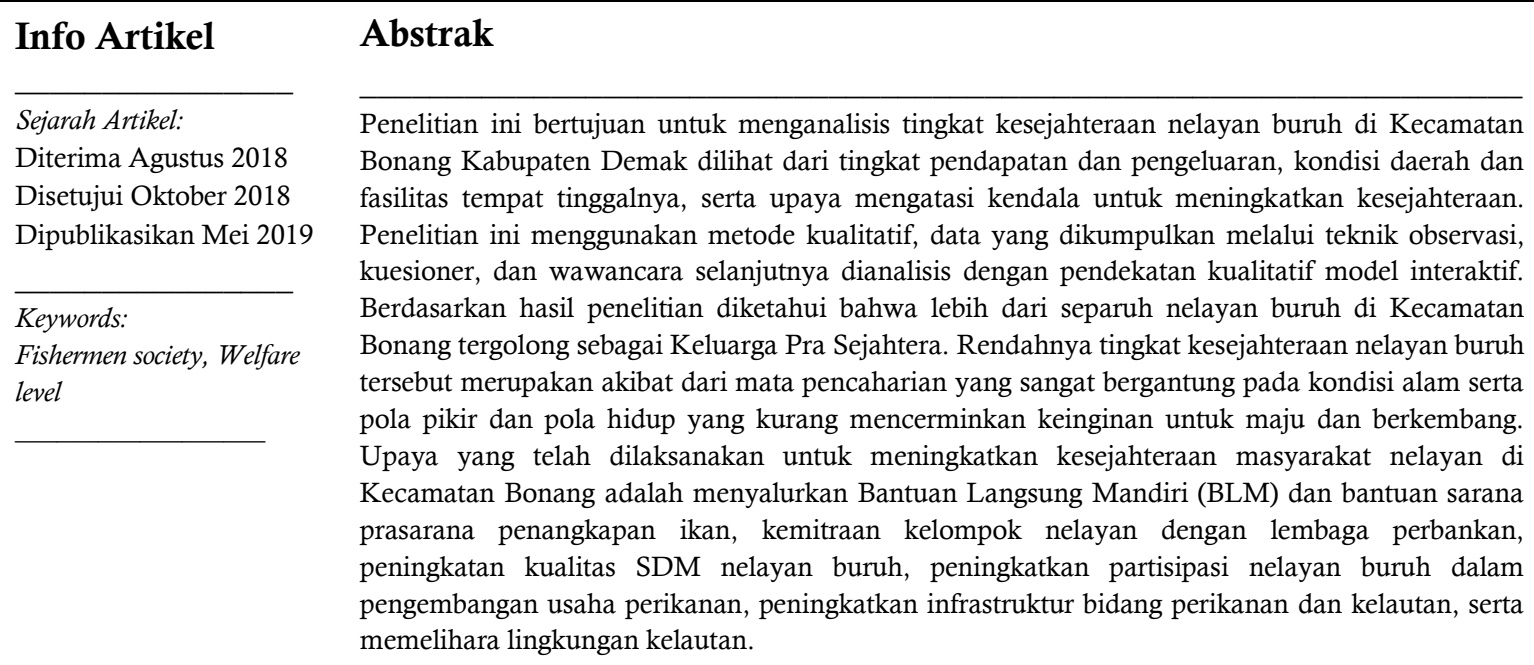

\begin{abstract}
This study was purposed to analyse fishermen welfare level in Kecamatan Bonang Kabupaten Demak viewed in terms of income and expense, environmental condition and residence facility, and efforts taken to solve fishermen society obstacles in order to improve their prosperity. This was included in qualitative study. Data was collected through observation, questionnaire, and interview techniques and analysed using interactive model qualitative approach. According to study result, it was found that more than a half of fishermen quantity in Kecamatan Bonang was classified as Unprosperous Family. Low level of fishermen welfare was caused by working dependence of natural condition and state of mind and lifestyle that lack of improvement wish. Some efforts taken to improve people welfare in Kecamatan Bonang were as follows: distributing Bantuan Langsung Mandiri (BLM) and fishing equipment aid, building fishermen group cooperation with banking institution, improving fishermen resource quality, improving fishermen participation to develop fishery business, improving fishery and marine infrastructure, and maintaining marine environment.
\end{abstract}

\footnotetext{
${ }^{\triangle}$ Alamat korespondensi:

J1. Erlangga Tengah No.17, Semarang, 50229

E-mail: diandaru7@gmail.com
} 


\section{PENDAHULUAN}

Masalah kemiskinan merupakan salah satu persoalan mendasar yang menjadi pusat perhatian di negara manapun. Kemiskinan merupakan masalah lintas zaman, kenyataan ini kiranya menjadi latar belakang mengapa kemiskinan menjadi masalah yang mendapat perhatian besar. Kemiskinan merupakan masalah yang tidak dapat dipisahkan apabila kita hendak membicarakan mengenai kesejahteraan. Kesejahteraan merupakan harapan setiap manusia. Kesejahteraan tidak akan terwujud jika masyarakat masih hidup dalam keadaan miskin. Dengan demikian kemiskinan harus diatasi karena merupakan suatu bentuk ketidaksejahteraan yang menggambarkan kondisi yang serba kurang dalam pemenuhan kebutuhan, terutama kebutuhan ekonomi.

Kemiskinan di Indonesia dapat kita saksikan di berbagai daerah. Badan Pusat Statistik (BPS), dengan perhitungan berbeda dari Bank Dunia, mengumumkan angka kemiskinan di Indonesia sebesar 28,59 juta orang (11,22 persen) pada tahun 2015. Angka tersebut diperoleh berdasarkan ukuran garis kemiskinan. Sebagian besar penduduk miskin di Indonesia berada di daerah pesisir dan pedesaan (BPS, 2015). Masyarakat pesisir yang sebagian besar berprofesi sebagai nelayan, terutama kelompok nelayan buruh, hingga saat ini nasibnya masih sangat mengkhawatirkan. Nelayan buruh yang mencapai lebih dari 22 persen jumlah penduduk Indonesia hidup di bawah garis kemiskinan dan menjadi golongan yang paling terpinggirkan. Besarnya potensi kelautan, dimana wilayah pesisir memiliki sumber daya yang sangat besar, belum mampu memberikan kesejahteraan bagi kelompok nelayan buruh. Kondisi tersebut tentu sebuah ironi, karena besarnya potensi sektor kelautan seharusnya mampu memberi kontribusi terhadap peningkatan kesejahteraan masyarakat nelayan. Sektor kelautan juga semestinya memberikan kontribusi yang maksimal terhadap Produk Domestik Bruto (PDB).

Rendahnya kesejahteraan masyarakat pesisir pada umumnya disebabkan oleh kurangnya keterampilan dalam sektor perikanan, kurangnya sarana prasarana pendukung usaha, belum dioptimalkan sumber daya alam lain di luar sektor perikanan, pengaruh budaya dan paradigma yang sudah tertanam, serta rendahnya tingkat pendidikan.

Secara prinsip setiap pengembangan usaha untuk meningkatkan taraf hidup masyarakat nelayan yang memanfaatkan sumber daya pesisir dan laut merupakan suatu proses perubahan yang sering menyebabkan perubahan-perubahan pada sumber daya alam sekitarnya sehingga dalam perencanaan pada suatu sistem ekologi pesisir dan laut perlu diperhatikan kaidah-kaidah ekologis yang berlaku untuk mengurangi akibat negatif yang merugikan bagi kelangsungan pembangunan itu sendiri (Bengen, 2000).

Meskipun potensi sumber daya di daerah pesisir sangat melimpah, kenyataannya masih banyak masyarakat di pesisir berada dalam kondisi kurang sejahtera, bahkan rawan kemiskinan, serta cenderung terpinggirkan. Kondisi seperti ini menuntut kebijakan pembangunan ekonomi nasional agar lebih memperhatikan masyarakat pesisir dan pulaupulau kecil sebagai bagian integral dari pembangunan kelautan dan perikanan. Mengingat potensi sumber daya alam yang ada, seharusnya masyarakat pesisir merupakan masyarakat yang sejahtera, terutama secara ekonomi. Fakta tentang kondisi kurang sejahtera yang dialami oleh masyarakat kelompok nelayan buruh juga terjadi di wilayah bagian barat Kecamatan Bonang, Kabupaten Demak. Sebagian besar penduduk di wilayah bagian barat Kecamatan Bonang merupakan nelayan buruh yang mengandalkan ikan tangkapan sebagai mata pencahariannya. Selain harus berhadapan dengan kondisi alam yang turut menentukan banyak atau sedikitnya hasil tangkapan, masyarakat pesisir ditengarai masih belum terpenuhi hak-hak dasarnya seperti pangan, kesehatan, pendidikan, pekerjaan, dan kondisi tempat tinggal.

Nelayan buruh di sekitar Pantai Moro Kecamatan Bonang menyebar di Desa Morodemak, Desa Margolinduk dan Desa Purworejo. Nelayan buruh dari ketiga desa tersebut merupakan sebagian besar nelayan yang melakukan kegiatan harian di kawasan Pelabuhan Pendaratan Pantai (PPP) 
Morodemak. Kegiatan usaha yang mereka jalani relatif berskala kecil serta memiliki tingkat kemandirian dan kelanjutan usaha yang rentan terhadap perubahan keadaan. Kabupaten Demak mempunyai potensi sumber daya perikanan yang masih cukup besar, namun perilaku usaha penangkapan yang dijalani oleh nelayan buruh mencerminkan bahwa tingkat keberdayaannya masih rendah. Rendahnya tingkat keberdayaan nelayan buruh ini menimbulkan masalah bagi mereka sendiri dalam hal pencapaian kesejahteraan.

Berdasarkan latar belakang di atas, perlu dilakukannya suatu kajian mengenai tingkat kesejahteraan masyarakat nelayan buruh, khususnya di Kecamatan Bonang, faktor yang menghambat sehingga nelayan buruh sulit mencapai kesejahteraan, serta upaya guna mengatasi kendala yang dihadapi nelayan buruh untuk mencapai kesejahteraan.

Masyarakat nelayan buruh di Kecamatan Bonang, sebagaimana nelayan pada umumnya, adalah suatu kelompok masyarakat yang kehidupannya tergantung langsung pada hasil laut, baik dengan cara melakukan penangkapan ataupun budidaya serta tinggal di pinggir pantai (Mulyadi, 2005). Batasan lain tentang nelayan menurut Gordon (Satria, 2002 dalam Deden, 2011) adalah orang yang melakukan penangkapan ikan baik di perairan laut maupun di perairan umum dengan menggunakan seperangkat alat tangkap ikan. Nelayan sering didefinisikan sebagai orang yang melakukan kegiatan penangkapan ikan di laut.

Kesejahteraan merupakan permasalahan serius yang harus dihadapi oleh Bagi kelompok nelayan buruh. Kesejahteraan menurut World Bank (2000) dapat diukur dari kekayaan yang dimiliki seseorang, kesehatan, gizi, pendidikan, asset, perumahan, dan hak-hak tertentu dalam masyarakat. BKKBN membagi tingkat kesejahteraan keluarga menjadi lima kelompok, yaitu Keluarga Pra Sejahtera, Keluarga Sejehtera I, II, III, dan Keluarga Sejahtera III Plus.

Kesejahteraan dalam konsep kemiskinan dapat dibedakan menjadi dua pendekatan utama, yaitu pendekatan welfarist dan non-welfarist (Ravallion,1994).
Pendekatan welfarist yang menitikberatkan pada perbandingan kesejahteraan ekonomi, yang juga disebut sebagai standar hidup atau pendapatan. Dasar dari pendekatan welfarist terhadap kemiskinan adalah adanya pernyataan bahwa penilaian terhadap kesejahteraan seseorang harus konsisten dengan urutan preferensi yang dinyatakan oleh orang tersebut.

Pendekatan non-welfarist yang memiliki dua pendekatan utama yaitu pendekatan kebutuhan atau disebut juga dengan functionings approach atau dimensions approach dan pendekatan kemampuan (capabilities). Pendekatan functionings yang dimaksud menitikberatkan pada capaian beberapa aspek mutidimensi dasar, seperti pemenuhan gizi, kesehatan, keamanan, harapan hidup dan lainnya. Sedangkan pendekatan kemampuan menitikberatkan pada "kemampuan" seseorang untuk berfungsi dengan baik di masyarakat.

Perihal rendahnya kesejahteraan nelayan buruh, menurut Rahmatullah (2010) ada lima masalah pokok yang menjadi penyebabnya, yaitu Kondisi alam. Kompleksnya permasalahan kemiskinan masyarakat nelayan terjadi disebabkan masyarakat nelayan hidup dalam suasana alam yang keras yang selalu diliputi ketidakpastian dalam menjalankan usahanya. Tingkat pendidikan nelayan. Nelayan yang miskin umumnya belum banyak tersentuh teknologi modern, kualitas sumber daya manusia rendah dan tingkat produktivitas hasil tangkapannya juga sangat rendah.

Pola kehidupan nelayan. Pola hidup konsumtif menjadi masalah laten pada masyarakat nelayan, dimana pada saat penghasilan banyak, tidak ditabung untuk persiapan paceklik, melainkan dijadikan kesempatan untuk membeli kebutuhan sekunder. Pemasaran hasil tangkapan. Tidak semua daerah pesisir memiliki Tempat Pelelangan Ikan (TPI). Hal tersebut membuat para nelayan terpaksa untuk menjual hasil tangkapan mereka kepada tengkulak dengan harga di bawah harga pasar. Program pemerintah yang belum memihak nelayan, kebijakan pemerintah yang tidak memihak masyarakat miskin, banyak kebijakan terkait penanggulangan kemiskinan bersifat top- 
down dan selalu menjadikan masyarakat sebagai objek, bukan subjek. Kebijakan yang pro nelayan mutlak diperlukan, yakni sebuah kebijakan sosial yang akan mensejahterakan masyarakat dan kehidupan nelayan. Berdasarkan latar belakang masalah di atas maka tujuan dalam penelitian ini adalah untuk menganalisis tingkat kesejahteraan nelayan buruh di Kecamatan Bonang Kabupaten Demak dilihat dari tingkat pendapatan dan pengeluaran, kondisi daerah dan fasilitas tempat tinggalnya, serta upaya mengatasi kendala untuk meningkatkan kesejahteraan.

\section{METODE PENELITIAN}

Penelitian ini dimaksudkan untuk tingkat kesejahteraan masyarakat nelayan buruh dengan memperhatikan aspek kelestarian lingkungan sehingga cocok dilakukan di kawasan pesisir. Lokasi penelitian ini adalah desa pesisir yang terdapat di Kecamatan Bonang Kabupaten Demak yang memenuhi kriteria yakni memiliki mayoritas masyarakat yang berprofesi sebagai nelayan tangkap, yaitu Desa Margolinduk, Desa Morodemak dan Desa Purworejo. Untuk memenuhi kebutuhan data, maka penelitian dilakukan selama enam bulan mulai dari kegiatan penyusunan rencana penelitian, sampai dengan analisis data dan penyusunan hasil penelitian.

Penelitian ini mencakup populasi yang cukup besar yaitu masyarakat nelayan buruh di Kecamatan Bonang yang berjumlah 3.844 orang. Untuk mempermudah pengumpulan data, maka dilakukan penarikan sampel dengan teknik simple random sampling (sampel acak sederhana) dimana jumlah sampel ditetapkan dengan rumus Slovin (Umar, 2004). Melalui penghitungan, diperoleh sampel sekaligus responden penelitian sebanyak 97 orang.

Sesuai dengan lingkup penelitian, maka variabel yang akan diteliti adalah tingkat kesejahteraan masyarakat pesisir. Kriteria kesejahteraan yang digunakan didasarkan pada kriteria dari BKKBN yang dirangkum dalam 7 indikator, yaitu pendapatan dan konsumsi keluarga, keadaan tempat tinggal, fasilitas tempat tinggal, kesehatan anggota keluarga, kemudahan menyekolahkan anak, kemudahan mendapat fasilitas transportasi, dan partisipasi sosial.

Pengumpulan data primer yang diperlukan dilakukan dengan menggunakan teknik observasi, penyebaran kuesioner, wawancara dan dokumentasi. Sedangkan data sekunder dikumpulkan melalui studi pustaka (library research). Data yang berhasil dikumpulkan selanjutnya dianalisis secara kualitatif dengan langkah-langkah merujuk pada model interaktif (interactive model) yang dikemukakan oleh Miles dan Huberman (Silalahi, 2012), yang meliputi kegiatan reduksi data (data reduction), penyajian data (data display), serta penarikan kesimpulan dan verifikasi (conclusion drawing/verifying).

\section{HASIL DAN PEMBAHASAN}

Tabel 1 pada lampiran memberikan gambaran mengenai kesejahteraan nelayan buruh di Kecamatan Bonang sebagai berikut:

Keadaan tempat tinggal, tempat tinggal atau rumah merupakan salah satu kebutuhan primer. Sebuah keluarga dapat dikatakan hidup layak apabila memiliki tempat tinggal yang layak pula. Selain sebagai kebutuhan primer, tempat tinggal atau rumah juga dapat menjadi penanda kelas sosial keluarga yang menempatinya. Diketahui bahwa hanya sebagian kecil nelayan buruh yang diteliti menempati rumah yang atap, lantai, dan dindingnya dalam kondisi baik atau rusak. Fakta empiris dari hasil pengamatan peneliti menunjukkan bahwa sebagian besar rumah nelayan buruh di Kecamatan Bonang, khususnya di Desa Purworejo, Morodemak, dan Margolinduk, merupakan bangunan semi permanen. Banyak di antara rumah yang ada masih berlantai tanah dan berdinding papan kayu ataupun bilik bambu seluruhnya atau setengah tembok. Selain itu, luas rumah sebagian besar keluarga nelayan buruh di Kecamatan Bonang juga kurang mencukupi untuk ditinggali oleh anggota keluarga. Kenyataan tersebut menunjukkan bahwa banyak nelayan buruh di Kecamatan Bonang kurang sejahtera jika dilihat dari kondisi rumah tempat tinggalnya.

Fasilitas tempat tinggal, diketahui bahwa tempat tinggal sebagian besar nelayan buruh tidak dilengkapi dengan jamban. Menurut 
pengamatan peneliti, keluarga elayan buruh lebih banyak memanfaatkan fasilitas MCK (Mandi, Cuci, Kakus) umum serta sungai yang ada di dekat rumah mereka. Belum terbangun kesadaran pada diri masyarakat nelayan untuk membuat jamban di rumah. Adapun dalam hal sumber air bersih, masih ada nelayan buruh yang rumahnya belum dilengkapi dengan sumur. Dalam hal penerangan, seluruh rumah nelayan buruh telah dialiri listrik dari PLN. Demikian pula dalam hal penggunaan bahan bakar rumah tangga, seluruh nelayan buruh telah terkena konversi dari minyak tanah dan kayu bakar ke bahan bakar gas (LPG).

Konsumsi Keluarga, kesejahteraan suatu keluarga dapat dinilai dari penghasilan dan konsumsinya, terutama konsumsi kebutuhan primer berupa pangan dan sandang. Diketahui bahwa sebagian besar nelayan buruh telah mampu memenuhi kebutuhan pangan keluarganya, dimana setiap anggota keluarga dapat makan paling sedikit dua kali dalam sehari serta mampu mengkonsumsi daging/ikan/telur setidaknya sekali dalam seminggu. Dalam hal pemenuhan kebutuhan sandang, sebagian besar nelayan buruh mempunyai pakaian yang berbeda untuk di rumah, bekerja atau sekolah, dan untuk bepergian serta mampu membeli satu stel pakaian baru dalam setahun. Kemampuan memenuhi kebutuhan sandang dan pangan tersebut didukung oleh penghasilan nelayan buruh yang sebanding dengan pengeluaran. Bahkan ada nelayan buruh yang dapat menyisihkan penghasilannya untuk ditabung. Hal ini tgidak lepas dari adanya anggota keluarga selain kepala keluarga yang telah bekerja.

Kesehatan keluarga, seluruh nelayan buruh menyatakan bahwa dalam tiga bulan terakhir anggota keluarga dalam keadaan sehat. Meskipun demikian, seluruh nelayan buruh sepakat bahwa apabila ada anggotanya yang sakit tentu akan dibawa ke rumah sakit ataupun sarana kesehatan yang ada. Khusus untuk nelayan buruh yang berada dalam usia subur, pada umumnya mengikuti program Keluarga Berencana (KB).

Kemudahan menyekolahkan anak, sebagian besar nelayan buruh mempunyai kesadaran yang baik terhadap kewajiban belajar dan berpendidikan dasar. Angka buta huruf di Kecamatan Bonang terhitung rendah. Namun, tidak banyak nelayan buruh yang mau dan mampu menyekolahkan anak ke jenjang pendidikan yang lebih tinggi. Bahkan banyak anak yang baru lulus SD atau SMP yang tidak meneruskan pendidikan formalnya.

Fasilitas Transportasi, tidak ada satu pun nelayan buruh yang memiliki kendaraan roda empat dalam bentuk apapun. Kendaraan yang umumnya dimiliki nelayan buruh pada umumnya adalah sepeda motor. Untuk memenuhi kebutuhab transportasi, nelayan buruh cukup mengandalkan sarana transportasi umum. Partisipasi Sosial, sebagian besar nelayan buruh mempunyai kehidupan sosial yang baik, di dalam keluarga ataupun di lingkungan mayaakat. Hampir seluruh nelayan buruh menyatakan sering ikut dalam kegiatan sosial kemasyarakatan dan secara teratur menyumbang untuk kegiatan sosial.

Secara garis besar, dapat dikemukakan kondisi kesejahteraan masyarakat nelayan buruh di Kecamatan Bonang berdasarkan kategori keluarga sejahtera sebagai berikut.

Tabel 2. Kategori Keluarga Nelayan Buruh Kecamatan Bonang

\begin{tabular}{|c|c|c|c|}
\hline No & $\begin{array}{l}\text { Kategori } \\
\text { Keluarga }\end{array}$ & Jumlah & $\%$ \\
\hline 1 & $\begin{array}{ll}\text { Keluarga } & \text { Pra } \\
\text { Sejahtera } & \end{array}$ & 71 & 73,2 \\
\hline 2 & $\begin{array}{l}\text { Keluarga } \\
\text { Sejahtera I }\end{array}$ & 22 & 22,68 \\
\hline 3 & $\begin{array}{l}\text { Keluarga } \\
\text { Sejahtera II }\end{array}$ & 4 & 4,12 \\
\hline 4 & $\begin{array}{l}\text { Keluarga } \\
\text { Sejahtera III }\end{array}$ & 0 & 0 \\
\hline 5 & $\begin{array}{l}\text { Keluarga } \\
\text { Sejahtera III plus }\end{array}$ & 0 & 0 \\
\hline \multicolumn{2}{|c|}{ Jumlah } & 97 & 100 \\
\hline
\end{tabular}

Sumber: Data penelitian 2016

Tabel 2 memperlihatkan bahwa sebagian besar nelayan buruh tergolong dalam kelompok Keluarga Pra Sejahtera. Hal ini menandakan bahwa banyak nelayan buruh yang rentan karena terlalu dekat dengan garis kemiskinan. Ada dua faktor yang menyebabkan 
sulitnya masyarakat nelayan buruh terlepas dari kemiskinan dan mencapai derajat sejahtera, yaitu:

Kondisi alam, sesuai dengan mata pencaharian utama sebagai nelayan ikan tangkap, masyarakat nelayan buruh di Kecamatan Bonang sangat bergantung pada kemurahan alam. Apabila kondisi iklim dan cuaca sedang baik, maka penghasilan cukup untuk memenuhi kebutuhan hidup, bahkan terkadang lebih. Sebaliknya, kondisi iklim dan cuaca dapat menyebabkan nelayan mengurungkan niat untuk pergi ke laut. Ketergantungan terhadap kondisi alam seperti itu berakibat pada tangkapan serta penghasilan nelayan buruh.

Pola pikir dan pola hidup nelayan, pola hidup konsumtif menjadi masalah laten pada nelayan buruh. Banyak di antara mereka yang cenderung berpola hidup konsumtif ketika hasil melaut melimpah. Penghasilan yang besar tidak ditabung untuk persiapan masa paceklik melainkan digunakan untuk membeli kebutuhan sekunder bahkan tersier. Pola hidup konsumtif seperti ini mengakibatkan masyarakat nelayan menghadapi kesulitan manakala harus memenuhi kebutuhan dasar sementara kondisi alam tidak memungkinkan dirinya pergi melaut.

Berkenaan dengan kondisi masyarakat nelayan pada umumnya dan nelayan buruh pada khususnya, Pemerintah Kabupaten Demak berupaya memaksimalkan pemberdayaan masyarakat nelayan sehingga dapat mencapai derajat sejahtera. Beberapa upaya tersebut antara lain adalah upaya peningkatan kesejahteraan nelayan buruh melalui penyaluran BLM yang bersumber dari APBD, hibah sarana prasarana penangkapan, serta kemitraan antara nelayan dengan bank melalui Kelompok Usaha Bersama (KUB).

Peningkatan kualitas sumber daya manusia nelayan buruh melalui sosialisasi tentang optimalisasi pengelolaan sumber daya laut dengan disertai pelatihan-pelatihan penguasaan teknologi penangkapan ikan dan peningkatan kemampuan berwirausaha. Peningkatan partisipasi masyarakat nelayan dalam pengembangan usaha perikanan melalui pengembangan kemitraan dan kelembagaan nelayan melalui forum nelayan berupa KUB. Adanya KUB diharapkan dapat memudahkan nelayan untuk menjalin kerja sama dan kemitraan dengan lembaga penyediaan modal (lembaga keuangan) serta perusahaan skala besar. Peningkatan infrastruktur bidang perikanan dan kelautan melalui penertiban izin usaha serta pembangunan pelabuhan perikanan dan tempat pelelangan ikan. Pemeliharaan lingkungan kelautan dengan melakukan pengawasan daerah pesisir dan melakukan konservasi ekosistem laut serta menindak tegas para pelanggar aturan kelautan yang berlaku.

\section{SIMPULAN}

Lebih dari separuh masyarakat nelayan buruh di Kecamatan Bonang merupakan Keluarga Pra Sejahtera atau dapat dikatakan masih berkutat dalam lingkaran kemiskinan. Tingkat kesejahteraan yang tergolong rendah tersebut merupakan akibat dari kebergantungan nelayan terhadap kondisi alam (iklim dan cuaca) serta pola pikir dan pola hidup yang kurang mencerminkan keinginan untuk maju. Untuk mengatasi kondisi tersebut, Pemerintah Kabupaten Demak telah mengupayakan penyaluran BLM, bantuan sarana prasarana penangkapan ikan, mengusahakan kemitraan antara kelompok nelayan dengan lembaga perbankan, meningkatkan kualitas sumber daya manusia masyarakat nelayan, meningkatkan partisipasi masyarakat nelayan dalam pengembangan usaha perikanan, meningkatkan infrastruktur bidang perikanan dan kelautan, serta menggalakan pemeliharaan lingkungan kelautan.

\section{DAFTAR PUSTAKA}

Bengen, D.G. 2000. Pengenalan dan Pengelolaan Ekosistem Mangrove. Bogor: Pusat Kajian Sumberdaya Pesisir dan Lautan IPB.

Dahuri, R. 2000. Pemberdayagunaan Sumber Daya Kelautan untuk Kesejahtraan Rakyat. Jakarta: Lembaga Informasi dan Studi Pembangunan Indonesia (LISPI).

Laode, Deden. 2011. Perubahan Sosial Ekonomi Nelayan Pulau Barrang Lompo. http://www.dedenbinlaode.web.id/2011/0 
5/perubahan-sosial-ekonomi-nelayandi.html.

Mulyadi, Subri. 2005. Ekonomi Kelautan. Jakarta: RajaGrafindo Persada.

Rahmatullah. 2010. Menanggulangi Kemiskinan Nelayan.

http://www.rahmatullah.net/2010/05/men anggulangi-masalah-kemiskinan.html

Silalahi. 2012. Metode Penelitian Sosial. Bandung: Refika Aditama.
Umar, Husein. 2004. Riset Sumber Daya Manusia Dalam Organisasi. Jakarta: PT.Gramedia Pustaka Utama.

Ardhianto, \& Haryati. 2016). PENGARUH PENDAPATAN NELAYAN PERAHU RAKIT TERHADAP POLA KONSUMSI WARGA DESA SURODADI KECAMATAN SAYUNG KABUPATEN DEMAK. Economics Development Analysis Journal, 5(1). doi:10.15294/edaj.v5i1.10774. 
Lampiran Tabel 1. Kondisi Kesejahteraan Nelayan Buruh Kecamatan Bonang

\begin{tabular}{llll}
\hline \multirow{2}{*}{ No } & \multicolumn{1}{c}{ Indikator } & Jumlah & $\%$ \\
\hline 1 & Makan 2 kali sehari atau lebih. & 95 & 97,9 \\
2 & Pakaian beda untuk di rumah/bekerja/sekolah/bepergian. & 94 & 96,9 \\
3 & Rumah beratap, berlantai, dan dinding yang baik. & 30 & 30,9 \\
4 & Yang sakit dibawa ke sarana kesehatan. & 97 & 100 \\
5 & Pasangan usia subur ber-KB. & 94 & 96,9 \\
6 & Anak umur 7 - 15 tahun bersekolah. & 87 & 89,6 \\
7 & Punya sumber air bersih. & 89 & 91,75 \\
8 & Menggunakan penerangan listrik. & 97 & 100 \\
9 & Punya sarana kakus/jamban sendiri & 43 & 44,3 \\
10 & Menggunakan bahan bakar gas/listrik. & 97 & 100 \\
11 & Anggota keluarga beribadah sesuai agamanya. & 97 & 100 \\
12 & Sekali seminggu makan daging/ikan/telur. & 97 & 100 \\
13 & Memperoleh minimal 1 stel pakaian baru dalam setahun. & 89 & 91,75 \\
14 & Luas lantai rumah minimal 8 m ${ }^{2}$ per penguhuni rumah. & 10 & 10,3 \\
15 & 3 bulan terakhir anggota keluarga dalam keadaan sehat. & 97 & 100 \\
16 & Ada anggota keluarga yang bekerja. & 35 & 36,1 \\
17 & Anggota keluarga umur 10 - 60 tahun bisa baca tulis. & 97 & 100 \\
18 & Pasangan usia subur dengan 2 anak/lebih ber-KB. & 54 & 55,6 \\
19 & Dapat menyekolahkan anak ke jenjang lebih tinggi. & 59 & 60,8 \\
20 & Penghasilan per bulan sebanding dengan pengeluaran. & 69 & 71,1 \\
21 & Keluarga berupaya meningkatkan pengetahuan agama. & 97 & 100 \\
22 & Sebagian penghasilan keluarga ditabung. & 54 & 55,7 \\
23 & Keluarga makan bersama sambil berkomunikasi. & 79 & 81,4 \\
24 & Sering ikut dalam kegiatan masyarakat. & 94 & 96.9 \\
25 & Memperoleh informasi dari surat kabar/majalah/radio/TV. & 97 & 100 \\
26 & Tidak kesulitan mendapatkan kendaraan umum. & 97 & 100 \\
27 & Punya kendaraan roda 2 berkondisi baik & 63 & 64,9 \\
28 & Punya kendaraan roda 4 berkondisi baik. & 0 & 0 \\
29 & Secara teratur menyumbang untuk kegiatan sosial. & 93 & 95,9 \\
30 & Aktif sebagai pengurus perkumpulan sosial. & 10 & 10,3 \\
\hline
\end{tabular}

Sumber: Data penelitian 2016 